\title{
LIMA BEAN POD-BORER CATERPILLARS OF PUERTO RICO ON THEIR WILD HOSTS
}

\author{
By George N. Wolcotт, Entomologist, \\ Insular Experiment Station, Río Piedras, Puerto Rico
}

No observations on the various lima bean pod-borer caterpillars of Puerto Rico could be made during 1933-34, as no lima beans were commercially grown on the Island during that period. Experiments conducted during previous years in the attempted control of these caterpillars had been so inconclusive (1) that planting lima beans for the specific purpose of continuing them seemed hardly justified. Observations on these caterpillars were thus confined to what could be noted on their native hosts.

Quite by accident, a considerable number of plants of Crotalaria incana were discovered growing wild in an abandoned coconut grove on the beach between Mameyes and Luquillo, on June 25, 1933. Collections of mature pods, either green or brown, have since been made during every month in the year from these plants, or others supplanting them in the same locality, or from other plants growing elsewhere (Loíza Aldea and Isabela) under substantially similar environment. In most eases, the infestation of these pods by Etiella zinckenella Treit. was total, or very close to it, dropping below 90 per cent only during February, March and April, the minimum recorded (see table) being a very exceptional drop to only 60 per cent infestation for a small number of pods (40) on April 15, 1934. This appears 10 parallel, but not very closely, the previously recorded scarcity of this caterpillar in lima beans during the winter and early spring, and such seasonal variation is also indicated by the more careful observations made on all the pods collected from an artificial planting at Río Piedras. 


\section{Infestation By Caterpillars of Etiella zinckenella in Pods of Crotalaria incana GROwING:}

On Sandy Beaches

June 25, 1933 at Mameyes: 100\%

August 6, 1933 at Mameyes: 100\%

Sept. 12,1933 at Isabela: $85-90 \%$

Sept. 25 at Mameyes (160 pods): $90 \%$

Oct. 29 at Loíza (60 pods): $84 \%$

Nov. 12 at Mameyes ( 80 pods): $91 \%$

Dec. 3 at Mameyes: $91 \%$

Dee. 17 at Mameyes: $100 \%$

Jan. 28 at Mameyes: $100 \%$

March 11 at Mameyes: $87 \%$

March 29 at Mameyes: $93 \%$

April 15 at Mameyes (40 pods): $60.0 \%$

April 10 at Río Piedras (530 pods): $8 \%$

April 20 at Río Piedras (370 pods): $.00 \%$ April 30 at Río Piedras (220 pods): $.00 \%$

April 29 at Loíza:

(100 brown pods): $92 \%$

( 70 green pods): $80 \%$

\section{On Heavy Clay Soil}

July 2 at Río Piedras (175 pods): $35 \%$ July 19 at Río Piedras (490 pods): $37 \%$ Aug. 6 at Río Piedras (368 pods): 44\%

Aug. 16 at Río Piedras (360 pods): $35 \%$

Dee. 29 at Río Piedras (114 pods): 1.0\% Jan. 13 at Río Piedras (202 pods): $2.5 \%$ Jan. 25 at Río Piedras (220 pods): $4.0 \%$

Feb. 9 at Río Piedras (510 pods): $0.2 \%$ Feb. 20 at Río Piedras (600 pods): $13.3 \%$ Feb. 27 at Río Piedras (690 pods): $5 \%$ March 8 at Río Piedras (370 pods): $1 \%$

March 14 at Río Piedras (327 pods): $2 \%$ Mareh 20 at Río Piedras (258 pods): $2 \%$ March 27 at Río Piedras (220 pods): $8.6 \%$

May 14 at Río Piedras (330 pods): $26.0 \%$ May 15 at Río Piedras (158 pods): $50.0 \%$ June 25 at Mameyes (110 pods): $89 \%$ June 20 at Río Piedras (680 pods): $15.0 \%$

After the initial discovery of Crotalaria incana growing wild on the beach at Mameyes, search elsewhere showed that this species, although by no means as abundant as the common, bright, showyflowered Crotalaria retusa, is nevertheless often to be found, not only on sandy beaches, but almost anywhere in abandoned areas not closely pastured, especially along roadsides and railroad tracks. A few plants from various points close to Río Piedras, but all growing on heavy clay soil, had all pods free from infestation by Etiella. To determine whether this was mereìy an accident, or a normal condi- 
tion, a planting of a small bed on the Station grounds at Río Piedras was established, from which all pods were collected and examined. The results of these examinations, as shown in the accompanying table, indicates a comparable seasonal variation, together with a very definite freedom from infestation, apparently due to type of soil. Every effort was made to increase the infestation during the winter, as all infested pods from Mameyes were placed on the ground at the base of these plants, without any apparent effect at that time. These plants averaged about three feet in height before beginning to produce pods, and some attained a maximum height of four feet. A supplementary planting made at the end of January began to have flowers early in April, when the plants were only a foot high, and had matured pods by early in May, the maximum height being only 18 inches.

The pods of Crotalaria retusa, which never in Puerto Rico have been found infested with Etiella zinckenella, are smooth and shining; those of $C$. incana are distinctly hairy. Whether this is the character which determines the selection of these pods for oviposition by the female moths, or some other, can only be determined in countries where the number of alternate hosts is greater than in Puerto Rico.

On Crotalaria incana, the eggs are laid between the hairs, usually in the keel-shaped depression on the upper side of the pods, more rarely on the sides or beneath. "The egg is glistening white when first laid, but after a few days its upper surface becomes mottled with red spots" (2). Most of the eggs noted in Puerto Rico were slightly pinkish or flesh-colored, others showed the mottling noted by Dr. Flanders. In shape, the egg is oval, but rarely regular, most of those observed on Crotalaria being considerably flattened on the side towards the pod, and often somewhat pulled out of shape by the hairs between which they are laid. The reticulations on the egg-shell are often so irregular as to suggest no definite pattern, yet in other cases, especially when observed after the emergence of the caterpillar, they can be plainly seen to consist of a series of pyramids arranged like the conventionalized pineapple design. Out of the hundreds of eggs examined, only a single instance of parasitization by Trichogramma minutum Riley was noted.

Immediately before hatching, the egg is more or less dark orange towards the center. The just-hatched caterpillar is yellowish, with an enormous black head. It eats hairs and the outer skin of the pod first, making somewhat of a bower of silk and excrement and uneaten ends of the hairs, before burrowing inside. As many as eight eggs have been noted on a single Crotalaria pod, and often 
three and four are to be found, yet rarely does more than a single caterpillar occur within. Within the pod, the caterpillar feeds on the immature seeds, making an extensive network of silken fibers and entangled excrement within the pod before it attains full size. Its later growth stages-a greenish caterpillar with black or very dark head, and in the last instar with a clear pro-thoracic shield marked with black-have previously been described (1).

The wild beach sword bean, Conavalia maritima, grows in abundance on the beach at Mameyes, and every time a collection of Crotalaria incana pods was made, incidental observations were made on the beach beans to determine a possible seasonal variation in their infestation by Fundello cistipennis Dyar. This caterpillar is also found attacking the pods of Cassia occidentalis, a common shrub springing up after cultivated crops have been harvested, or growing along roadsides. In both hosts, heavy infestations were found every time search was made for them. A careful examination of flower sprays of Canavalia moritima picked at Mameyes December 1, 1933, indicated that buds and flowers, as well as pods in all early stages of development, were eaten by the caterpillars. The eggs were noted in considerable abundance, in practically all cases being laid on the calyx. If the calyx of the unopened bud is fresh and plump, the egg is laid in the depression where the lower lobes fold against the upper one. On the withered calyx, the egg is laid anywhere. As many as seven eggs on a single calyx were counted. The eggs are a dark intense pink, oval in outline, tightly glued to the plant surface, and somewhat flattened in contact with it. The upper surface is finely reticulate, with an irregular pattern of somewhat elongate polygons. When about to hatch, the egg becomes grey, and soon the head of the caterpillar can be seen in motion with its jaws chewing a hole in the side. As soon as the hole is large enough, the caterpillar crawls out without delay and moves away from the empty shell. Its head is relatively enormous in size, dark brown in color, the slender body being light yellowish brown, with a central darker stripe thru the middle to mark the position of the empty alimentary canal.

On Cassia occidentalis, the eggs of Fundella cistipennis are sometimes laid on the underside of the very tender leaves, but when flower sprays are present, the majority of the eggs are found at the base of the young pods, on its torus or receptacle: the scar left by the falling off of the withered flower. When laid in this depression, the egg appears quite flat and scale-like, being almost level on the 
upper, exposed surface, but even more convex where it fits into the crease of the torus.

The attempt at control of the lima bean pod-borers by means of spraying with pyrethrum was based on the assumption that this might kill the eggs or small caterpillars before they entered the pod. To test this possibility, branches of Crotalaria incana bearing many green pods on which the eggs of Etiello zinckenella had been laid were sprayed with pyragol, diluted 1 to 200 with rain water. Within the next few days, every egg hatched. The experiment was repeated, using a dilution of 1 to 100 , with the same results. A third spraying (of fresh pods) with a dilution of 1 to 75 caused considerable temporary curling of the leaves, and also had no effect on the eggs. Nor was any effect to be observed on the young caterpillars.

To duplicate this experiment with the eggs of Fundella cistipennis, bunches of freshly picked flower clusters of Canavalia maritimo were sprayed with pyragol, diluted 1 to 200,1 to 100 and 1 to 75 . In no case did this treatment prevent the hatching of the eggs, or kill any caterpillars. In all stages of growth, however, the caterpillars are readily susceptible to drowning, for all present overnight in pods below the water level were dead by the next morning.

These experiments indicate that the only possible value which pyrethrum might possess is in discouraging oviposition on sprayed plants. An experiment to determine this point, conducted on wild plants on the beach could not be kept under daily observation, and it was not until late in the summer of 1934 that the pods of Crotalaria incana at Río Piedras were sufficiently infested to be used for such an experiment. They had been planted in two rows, and one of these was sprayed with pyragol, diluted 1 to 100 with water, on August 16th, and again on August 20th, the other row being intended to serve as check. Unfortunately, the two rows were only a little over four feet apart, so that the fumes of the poison apparently also affected oviposition on the check. The first count made on the pods, August 27th, showed a drop from the July-August average of $38 \%$ to $11.1 \%$ on the sprayed row and $14.5 \%$ on the check row. The second examination of pods made on September 10th showed $16.5 \%$ infestation on 314 sprayed pods, as compared with $31.0 \%$ infestation on 83 check pods. These results are not entirely conclusive, but they appear to indicate that pyrethrum may have a definite value in preventing oviposition by the females of Etiella zinckenella. No comparable experiments with Fundella cistipennis were attempted. 
434 THE JOURNAL OF AGRICULTURE OF THE UNIVERSITY OF P. R.

BIBLIOGRAPHY

1. Wolcott, G. N. "The Lima Bean Pod-Borer Caterpillars of Puerto Rico."' The Jour. Dept. Agr., Puerto Rico, 17(3), 241-255, fig. 6, pl. 1. San Juan, July, 1933.

2. Flanders, S. E. "The Lima Bean Pod-Borer in California." Monthly Bull. Dept. Agr. California, 19 (6) : 409-421, fig. 4, re:. 6. Sacramento, June, 1930. 